\title{
HERPES ASSOCIATED ERITHEMA MULTIFORME (HAEM ) ON THE PSYCHOSOMATIC PATIENT : A CASE REPORT
}

Yayun Siti Rochmah*, Rochman Mujayanto**

*Oral and maxillofacial Departement, Fakultas Kedokteran Gigi Unissula Semarang

**Oral Medicine Departement, Fakultas Kedokteran Gigi Unissula Semarang

Correspondence: yayun@unissula.ac.id

Keywords:
HAEM, psychosomatic,
herpes virus

\section{PENDAHULUAN}

Masalah psikologi yang dialami seseorang apabila tidak segera ditangani dengan baik, maka akan dapat menimbulkan masalah pada organ (bagian) tubuh lainnya, salah satunya rongga mulut. Gangguan psikologis atau stres yang berlangsung lama dapat meningkatkan jumlah hormon stres yang mempengaruhi kondisi jaringan lunak dalam rongga mulut. (1) Masalah psikologis (Stres) kronik menimbulkan gangguan respon imun dan respon inflamasi. (2) Inflamasi yang berlebihan akan menyebabkan gangguan homeostasis mukosa mulut. Eritema multiformis sering bermanifestasi di ronggo mulut berupa lesi erosif cenderung berdarah dan menimbulkan keluhan nyeri hebat kadang-kadang diikuti dengan keluhan demam, lemas. EM sering dihubungkan dengan reaksi hipersensitivitas tipe IV yang disebabkan oleh berbagai pencetus diantara infeksi, obat, paparan sinar matahari dan pencetus lainnya. EM tergolong penyakit self-limiting, tetapi apabila tidak dilakukan perawatan dapat menimbulkan rasa nyeri, ketidaknyamanan, serta dapat mempengaruhi estetika dan aktivitas sosial, sehingga terjadi penurunan kualitas hidup. Tujuan laporan kasus ini adalah memaparkan kasus EM pada pasien dengan problema psikosomatis.

\section{METODE PENELITIAN}

Seorang mahasiswa perempuan berusia 23 tahun datang dengan keluhan mulutnya nyeri bila dipakai bicara atau makan sejak seminggu yang lalu. Kadang keluar darah segar disela-sela luka. Sudah dibawa ke dokter gigi dan diberi obat salep, tetapi keluhan tidak berkurang, bahkan semakin parah. Informasi dari orangtua, perempuan tersebut sedang dalam pengobatan 
psikiater (anti depresan) karena cemas yang berlebihan terkait dengan masalah kuliahnya. Riwayat alergi disangkal.

Pemeriksaan ekstraoral tampak mukosa bibir kemerahan, mudah berdarah, sedikit udem dan nyeri tekan, pemeriksaan intraoral, mukosa bukal kemerahan tidak merata, gingiva kemerahan, mudah berdarah, lidah dalam batas normal. Hasil pemeriksaan laboratorium sebagai berikut :

Tabel Temuan Artikel/Jurnal

\begin{tabular}{|c|c|c|c|c|}
\hline Jenis pemeriksaan & Hasil & Nilai rujukan & Satuan & Metode periksa \\
\hline Ig G Anti HSV 1 & 0,029 & $\begin{array}{l}\text { Negatif : }<0,6 \\
\text { Equivocal }:>=0,6-<1,0 \\
\text { Positif }:>=1,0\end{array}$ & COI & Elisa \\
\hline Ig M Anti HSV 1 & 1,54 & $\begin{array}{l}\text { Negatif : }<0,9 \\
\text { Equivocal }:>=0,9-<1,0 \\
\text { Positif }:>=1,0\end{array}$ & Index & Elisa \\
\hline
\end{tabular}
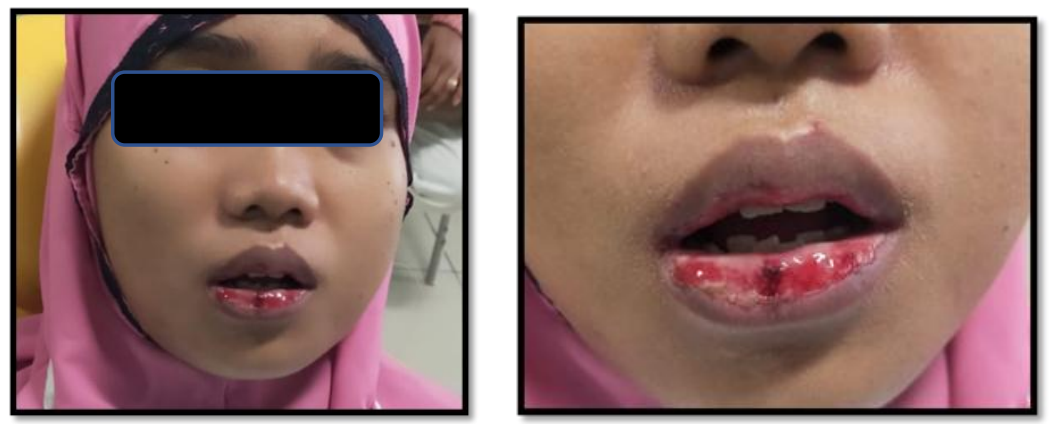

Gambar 1 : Klinis ekstraoral saat kunjungan I

Pasien didiagnosa sebagai HAEM (Herpes Assotiated Eritema Multiformis), pasien diberikan terapi krem kenalog, methisoprinol 3x $500 \mathrm{mg}$ dan acyclovir 3x 400mg, dan obat kumur Chlorhexidine digluconate 0,12\% sebagai antiseptik.
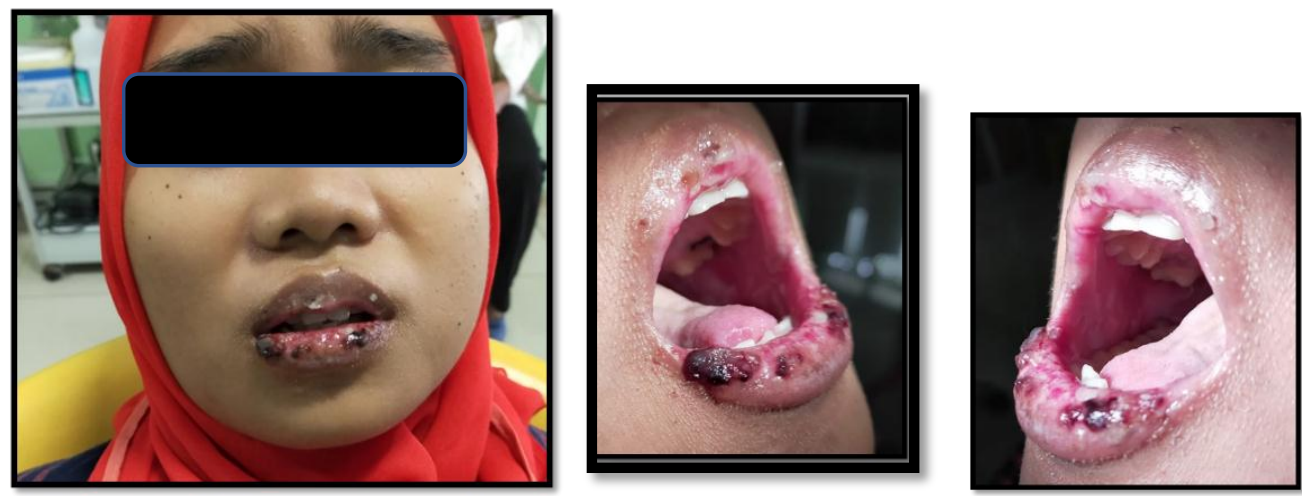

Gambar 2 . Klinis ekstraoral dan intraoral pada kunjungan ke 2 
Kontrol pertama saat hari kelima pasca terapi, dengan keluhan luka dibibir sudah mengering, tetapi masih sakit bila dipakai makan atau bicara. Obat psikosomatis tetap diminum secara teratur bersamaan dengan obat HAEM. Pemeriksaan klinis tampak seperti pada gambar 2, luka di bibir mengering, tidak ada darah segar, tampak sedikit lesi mirip krusta.
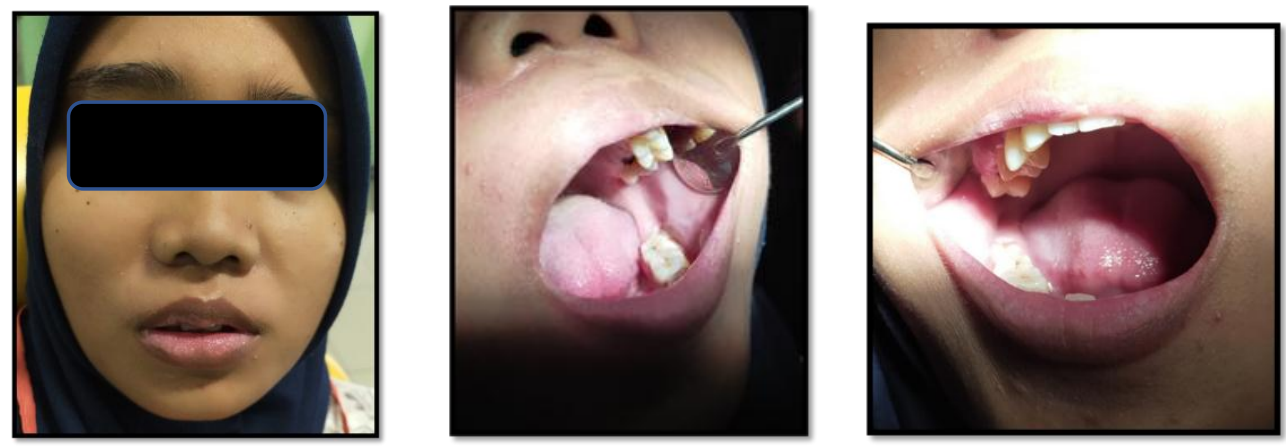

Gambar 3. Kondisi klinis pasien 2 minggu pasca terapi medikamentosa

Kontrol kedua saat 14 hari pengobatan. Keluhan sudah membaik, tidak ada rasa nyeri. Pemeriksaan klinis mukosa bibir dan bukal tampak normal seperti pada gambar 3 .

\section{DISKUSI}

Eritema multiformis merupakan salah satu bentuk kelainan di mukosa yang bersifat akut. Nama lain dari Eritema multiforme (EM) adalah eritema eksudativum multiforme yang dikenalkan pertama kali oleh Ferdinand von Hebra pada tahun 1866. Kelainan ini kadang dapat sembuh dengan sendirinya apabila faktor pencetusnya telah teratasi. ${ }^{(3)}$ Etiologi EM diprediksi akibat reaksi alergi terhadap jejas infeksi atau obat tertentu. Penyebab terbanyak adalah karena infeksi virus herpes simplex virus (HSV) sekitar $50-70 \%$ kasus atau sering disebut sebagai herpesassociated erythema multiforme (HAEM). Infeksi HSV dan EM sering terjadi bersamaan. Penyebab lainnya adalah infeksi Mycoplasma pneumoniae, virus Epstein-Barr, virus varisela zoster, virus hepatitis B dan $\mathrm{C}$, parvovirus B19, sitomegalovirus, serta infeksi jamur dan parasit. EM juga dapat terjadi akibat imunisasi, obat-obatan, penyakit autoimun, radiasi dan menstruasi, serta idiopatik. ${ }^{(4)}$

EM biasanya bersifat akut denga gejala prodromal ringan atau tanpa gejala. Demam, linfadenopati, malaise, nyeri kepala, batuk, nyeri tenggorokan biasanya muncul sebelum timbul lesi pada mukosa dan kulit. ${ }^{(5)}$. Lesi EM biasanya berupa krusta hemoragik kadang disertai deskuamasi dan mudah berdarah. Kondisi mudah berdarah merupakan gambaran klinis yang khas pada EM karena terjadi vaskulitis (inflamasi pembuluh darah) sehingga mukosa mudah berdarah. Diferensial diagnosa kasus ini adalah sindroma Stevens Johnson. Pada kasus ini tidak ditemukan lesi di kulit, sehingga dikategorikan sebagai EM minor. ${ }^{(6)}$

Terapi Psikosomatis dengan obat anti depresi dapat menimbulkan reaksi imunologi yang bermanifestasi di mukosa mulut, salah satunya EM. Reaksi obat yang merugikan ini kemungkinan disebabkan karena polimorphism gen sitokrom enzim P450, asetilasi dan metilasi obat dan beberapa varian genetik lainnya yang berperan pada respon imun (7). Terapi sistemik dalam hal ini terapi psikosomatis berupa anti depresan dapat merangsang respon hipersensitif imunoinflamasi 
spesifik dengan obat yang berbeda diperantai oleh immunoglobulin E- (lgE-) tipe I, Ig G tipe II, imun komplek tipe III dan reaksi sel T tipe IV, dimana masing-masing komponen tersebut dapat menyebabkan reaksi alergi pada mukosa mulut ${ }^{(8)}$. Berdasarkan teori tersebut, maka pasien ini ada dua kemungkinan pencetus EM yaitu infeksi HSV atau karena reaksi alergi obat anti depressan. Data dari anamnesa ibu pasien didapatkan keterangan bahwa pasien tersebut telah mengkonsumsi obat anti depressan sejak sebulan yang lalu, sedangkan keluhan pada mukosa mulut baru dirasakan dalam seminggu ini, sehingga dapat disimpulkan diagnosa EM disebabkan karena infeksi HSV1.

Terapi HAEM adalah dengan memberikan obat antivirus Acyclovir tablet untuk meredakan infeksi virus herpes. Pemberian methisoprinol 3x $500 \mathrm{mg}$ adalah suatu imunomodulator bertujuan untuk menginduksi differensiasi sel $\mathrm{T}$ dan respon limfoproliferatif yang dapat mengenal sel yang terinfeksi virus. Aplikasi Kortikosteroid secara topikal diharapkan mampu mengurangi reaksi inflmasi langsung pada mukosa yang sudah muncul lesi. Edukasi kepada pasien untuk senantiasa menjaga kebersihan rongga mulutnya dan memperbanyak konsumsi buah dan sayur untuk meningkatkan imunitas tubuh.

\section{Kesimpulan}

Kasus HAEM apabila dilakukan perawatan dengan tepat maka dapat sembuh dengan baik. Faktor pencetus harus dapat dikendalikan agar tidak menjadi rekurensi.

\section{DAFTAR PUSTAKA}

1. Simone Reuter, Subash C. Gupta, Madan M. Chaturvedi, and Bharat B. Aggarwal, Oxidative stress, inflammation, and cancer: How are they. 49(11), Houston, Texas: Free Radic Biol Med. 2010 December, 2010, Vol. 1. 1603-16.

2. Payal Katakwar, Rashmi Metgud, Smitha Naik,Rashu Mittal. , Maharashtra, Oxidative stress marker in oral cancer: $A$ review., India : Journal of Cancer Research and Therapeutics, April-June 2016, Vol. 12.

3. JC, Roujeau ,Erythema Multiforme.. p.4319., New York: McGraw-Hill : In: Goldsmith LA, Katz SI, Gilchrest BA, , 2012, Vol. 8.

4. K. A. Kamala, L. Ashok, and Rajeshwari G. Annigeri ,Herpes associated erythema multiforme. 4, s.l. : Contemp Clin Dent, 2011, Vol. 2. 372-75.

5. I Nyoman Gede Juwita Putra, Suniti, Nanan Nur'aeny, Indah Suasani Wahyuni , Suplementasi mikronutrien pada pasien eritema multiforme dengan penurunan kualitas eritrosit.. suppl 2, s.l.: Jurnal Kedokteran Gigi Universitas Padjadjaran. , Februari 2021, Vol. 32. 111-19.

6. Taqi, Syed Ahmed. Drug-induced oral erythema multiforme: $A$ diagnostic challenge., s.l. : Ann Afr Med, Jan-Mar 2018, Vol. 17. 43-5.

7. K. Shinkai, R. S. Stern, and B. U. Wintroub Cutaneous drug reactions . [book auth.] A. S. Fauci, S. L. Hauser, D. L. Longo, J. L. Jameson and J. Loscalzo D. L.Kasper. Harrison's Principles of Internal Medicine. USA : McGraw-Hill, 2015, Vol. 1.

8. R. A. G. Khammissa, R. Chandran, A. Masilana, J. Lemmer, and L. Feller, Adverse Immunologically Mediated Oral Mucosal Reactions to Systemic Medication: Lichenoid Tissue Reaction/InterfaceDermatitis-Stomatitis, Autoimmune Vesiculobullous Disease, andlgE-Dependent and Immune Complex Reactions.. s.l. : Hindawi Journal of Immunology Research, 2018. 10 pages. 